\title{
(C) OPEN ACCESS \\ Guidance for sports injury surveillance: the 20-year influence of the Australian Sports Injury Data Dictionary
}

\author{
Caroline F Finch, Carolyn Staines
}

\begin{abstract}
Australian Centre for Research into Injury in Sport and its Prevention (ACRISP), Federation University Australia, Ballarat, Victoria, Australia
\end{abstract}

\section{Correspondence to} Professor Caroline F Finch, Australian Centre for Research into Injury in Sport and its Prevention (ACRISP), Federation University Australia, Ballarat, Victoria 3353, Australia; c. finch@federation.edu.au

Received 10 September 2017 Revised 21 November 2017 Accepted 27 November 2017 Published Online First 27 December 2017

\begin{abstract}
Background Injury prevention requires information about how, why, where and when injuries occur. The Australian Sports Injury Data Dictionary (ASIDD) was developed to guide sports injury data collection and reporting. Sports Medicine Australia (SMA) disseminated associated data collection forms and an online tool to practitioners and the sports community. This paper assesses the long-term value, usefulness and relevance of the ASIDD and SMA tools.
\end{abstract}

Methods A systematic search strategy identified both peer-reviewed and grey literature that used the ASIDD and/or the SMA tools, during 1997-2016. A text-based search was conducted within 10 electronic databases, as well as a Google Image search for the SMA tools. Documents were categorised according to ASIDD use as: (1) collected injury data; (2) informed data coding; (3) developed an injury data collection tool and/or (4) reference only.

Results Of the 36 peer-reviewed articles, 83\% directly referred to ASIDD and 17\% mentioned SMA tools. ASIDD was mainly used for data coding $(42 \%)$, reference $(36 \%)$, data collection (17\%) or resource development (14\%). In contrast, $86 \%$ of 66 grey literature sources referenced, used or modified the SMA data collection forms. Conclusions The ASIDD boasts a long history of use and relevance. Its ongoing use by practitioners has been facilitated by the ready availability of specific data collection forms by SMA for them to apply to directly their settings. Injury prevention practitioners can be strongly engaged in injury surveillance activities when formal guidance is supported by user-friendly tools directly relevant to their settings and practice.

\section{INTRODUCTION}

The prevention of sports injury is a primary focus for health promotion agencies and sporting bodies across all levels of participation, from elite athletes to community sport to active recreational pursuits. According to the Translating Research into Injury Prevention Practice framework, ${ }^{1}$ injury surveillance provides essential data to drive the development and implementation of injury prevention strategies. Standardised injury data collection is therefore crucial to underpin the provision of safe opportunities for all those who participate in sport.

Injury surveillance is the standardised, routine and ongoing process of collecting data relating to injury occurrence and its causes. ${ }^{2}$ Worldwide, there are numerous injury surveillance systems used in specific sporting contexts. ${ }^{3}$ For example, the National Collegiate Athletic Association injury surveillance system is used specifically in the American collegiate sporting system ${ }^{4}$ and the International Olympic Committee's Injury Surveillance System has been used widely during large-scale multisport events. ${ }^{5}$ There is no nationwide sports injury surveillance system in Australia. However, since 1998, guidance for sports injury surveillance has been provided through the Australian Sports Injury Data Dictionary (ASIDD) ${ }^{6}$ and associated resources disseminated by the national sports medicine authority, Sports Medicine Australia (SMA).

\section{Contextual background to the Australian Sports Injury Data Dictionary development}

In Australia during the mid-late 1990s, considerable attention was given to the availability of robust injury surveillance systems, to support the need for data to inform injury prevention strategies. ${ }^{7-10}$ In 1997, the Australian Sports Injury Prevention Taskforce (ASIPT), which was a joint body representing the Australian Sports Commission and the Federal Department of Health, developed a national sports safety framework, Sportsafe Australia.9 ${ }^{11}$ A key recommendation from this framework was the development of a national sports injury surveillance system. ${ }^{71}$ The Sportsafe framework was in accord with the recommendations of an earlier national feasibility study into a national sports injury surveillance in Australia which had advocated for the development of standardised data collection procedures and coding systems specifically for the Australian sports setting. ${ }^{12}$ That feasibility study included a review of the sports injury surveillance practices of the time and a sports injury surveillance needs analysis. Key sports injury surveillance items were identified from the literature. Best practice from national and international injury surveillance systems were summarised, including from the then current Australian National Minimum Dataset for Injury Surveillance (NDS-IS), the currently used International Classification of Diseases Ninth Revision (ICD-9) and recent developments from the ICD Tenth Revision (ICD-10). These injury coding systems were the most widely used in Australia in the 1990s, but largely for hospital data collections (eg, hospital admissions data and emergency department presentations). Concurrently, in clinical sports medicine settings, there was increasing recognition of the value of the Orchard Sports Injury Classification Scheme (OSICS) ${ }^{13}$ for coding sports injury diagnoses.
To cite: Finch CF, Staines $C$. Inj Prev 2018;24:372-380. 
It was considered by the general sports injury prevention community that injury surveillance guidance for use outside of hospital settings was urgently required. This was particularly needed for clinical sports medicine practice and for field-side reporting of injuries as they occurred during sport participation. To achieve this, the Australian Sports Injury Data Working Party (ASIDWP) was established as a national committee by the ASIPT to provide standardised guidelines for the collection of sports injury data in Australia. It comprised experts from the fields of epidemiology, statistics, database management/computing, injury surveillance, sports administration and clinical sports medicine. Its efforts resulted in the publication of the ASIDD in $1998 .^{6}$

\section{Structure of the Australian Sports Injury Data Dictionary}

The ASIDWP agreed on a coding manual (ie, the ASIDD) which categorised data items with defined variables. Category 1 items were considered 'Core' and should be present in all data collection opportunities. Category 2 items were 'Strongly Recommended' to provide for additional injury related information, especially around their causation. Category 3 items were those 'Recommended' for further data related to the event. Elements of the items were chosen to be consistent with both the ICD and OSICS.

The development of the ASIDD addressed some of the issues in the area of injury of surveillance that were present at the time in Australia. For example, the earlier needs analysis demonstrated that sports injury data were being collected in a range of settings by a range of professionals with varying levels of expertise and data infrastructure; ${ }^{12}$ therefore, the document needed to be user friendly yet comprehensive. The primary injury surveillance data collection tool at the time in Australia was the NDS-IS V.2.1. However, this was not specifically designed for a sporting context and only captured specific information about 35 sports or recreational activities. To obtain a more comprehensive view of injury across a broader range of sports, the ASIDD included codes for more than 120 sports/physical activities. Additionally, the ASIDD provided codes to capture external injury factors implicated in sports injury causation such as sporting equipment, natural objects, structures or fittings, surface characteristics or climate. This was in agreement with the then International Classification of External Causes of Injury. ${ }^{14}$ To enhance reporting of the anatomical location of the injury, the ASIDD included an artist-designed body chart for clinical data recorders, in accordance with usual clinical practice.

\section{Development of standardised injury reporting forms}

Following from the earlier feasibility study, a prototype general sports injury data collection form had been developed by researchers, along with a supporting onsite computer-based data entry system. These were trialled at a large-scale multi-sport event, the 1995 World Police and Fire Games held in the Victorian capital city, Melbourne ${ }^{15}$ Based on this trial, the data collection form was refined and trialled again at another multiple sport event in Melbourne, the 1995 Australian Masters Games. ${ }^{16}$ The trials demonstrated the usefulness of these tools for sports injury surveillance and sports injury research in the Australian context. The trial findings were made available to the ASIDWP and the trialled form was adopted as a generic template and used as the standardised data collection form in the ASIDD. The form was modified slightly to provide 18 sport-specific variants that could readily be used by practitioners who wanted to collect sports injury data in their settings. When the ASIPT functions were transferred to SMA from the end of the 1990s, SMA provided open access to the generic form and the 18 sport specific forms on its website and still does today (see http://sma.org.au/ resources-advice/sports-injuries/injury-record-form/). These are available for access by both Australians and non-Australians.

A later development arising from the ASIDD, and led by the Victorian Branch of SMA, was the production of an online sports injury surveillance system-Sports Injury Tracker (http:// sma.org.au/resources-advice/sports-injuries/injury-reportingform/). This tool aimed to enable community-sports organisations to record, store and analyse sports injury data. This work by SMA-Victoria was fully funded over 6 years by the Victorian Government (via Sport and Recreation Victoria).

\section{Aims}

The purpose of this paper is to describe the extent to which the ASIDD has been employed over its 20 -year existence, including where, in what way and by whom. It is intended that the findings will contribute to ongoing discussions about the future value of ASIDD and the associated SMA resources (ie, the sport-specific injury surveillance data collection forms and the online Sports Injury Tracker web tool) as well as sports injury data collections globally.

\section{METHODS}

\section{Literature search}

To identify all literature that had used the ASIDD or SMA's associated injury reporting forms or SMA-Victoria's Sports Injury Tracker (hereafter collectively referred to as the SMA tools), two search strategies were employed for literature published before October 2016.

Text-based searches of both peer-reviewed and grey literature were conducted using databases (PubMed, CINHAL, MEDLINE, SPORTDiscus, Science Direct, Trove, ProQuest and British Library Ethos) and the Google Scholar/Google search engines. Searches were based on the following key words or phrases: Australian Sports Injury Data Dictionary; Sports Injury Data Dictionary; Sport Safe Australia Sports Injury Data Dictionary; Sportsafe Australia Sports Injury Data Dictionary; The Australian Sports Injury Data Working Party; Sports Injury Tracker; Australian Sports Injury Data Dictionary; injury reporting form; sports 'injury report' form.

Following the primary database search, the citation tracking option was employed to obtain additional articles that had referenced the tools. Articles were excluded if they were not available in the English language or if they were only available as a conference abstract. Peer-reviewed literature included published journal articles and theses. Grey literature included governmental, organisational and research reports and web-based material. The websites of sporting and sports medicine organisations were also searched.

The SMA tools included specifically designed anatomical images. Therefore, it was also possible to conduct searches looking for these unique images. A Google Images search was conducted using reverse image searching. Reverse image searching identifies key points within an image and searches the internet for key points found at the same locations on other images. ${ }^{17}$ Three variations of the anatomical images were used in the reverse image searches: entire chart (anterior body, posterior body and head); anterior/posterior views only; head only (figure 1). Results of the image searches were compared with the images unique to the SMA tools and only exact replications of the images were considered a match. 

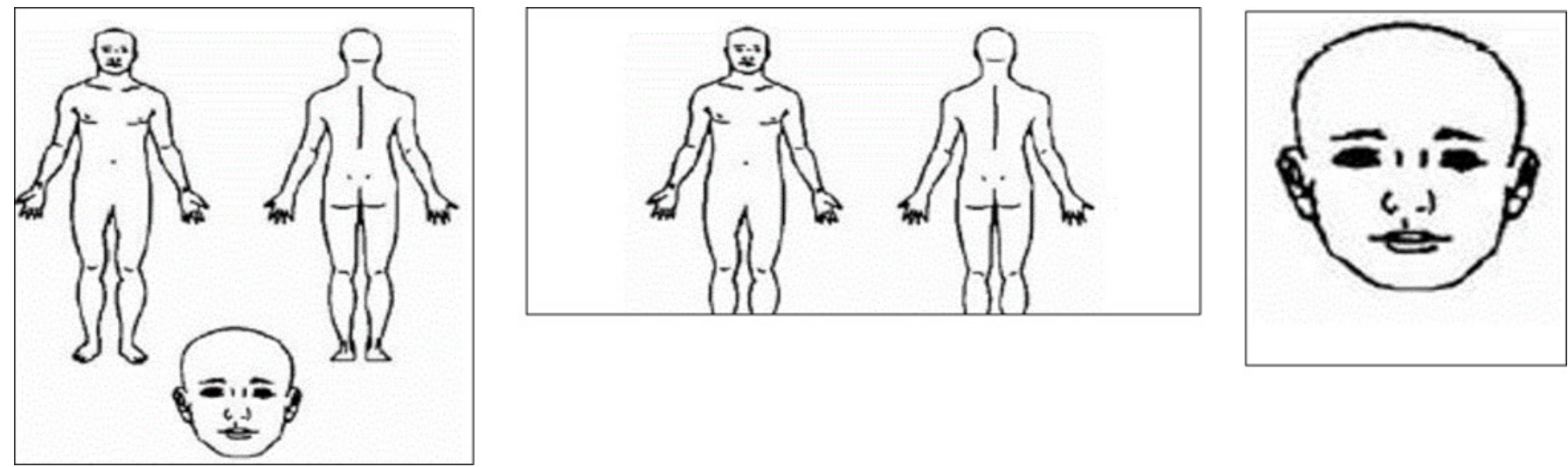

Figure 1 Images from the generic sports injury surveillance forms used in the reverse image searches in Google Images.

\section{Assessing how Australian Sports Injury Data Dictionary has been used}

Each identified document was scanned by eye and searched electronically, using key word/phrase searches, to determine how ASIDD and the SMA tools had been used. Their use was classified into four function categories:

1. Data collection: used to collect sports injury data.

2. Data analysis: ASIDD categories employed in data coding and/or reporting.

3. Tool development: used in the development of another injury data collection tool.

4. Reference only: mentioned in the text but not used for other purposes.

\section{RESULTS}

Key features of the identified documents are shown in table 1 (peer-reviewed literature) and table 2 (grey literature).

\section{Peer-reviewed sources}

As shown in table 1, ASIDD or the SMA tools (forms or Sports Injury Tracker) were mentioned in 36 peer-reviewed articles. The majority of these, 30 (83\%), referred to the ASIDD alone, while only $3(8 \%)$ mentioned the reporting forms and $3(8 \%)$ mentioned the injury tracker. The main use for the tools was data analysis, primarily data coding, 15 (42\%), while $6(17 \%)$ used them for data collection, 5 (14\%) used them as a resource for the development of other data collection tools and 13 (36\%) only referred to them in the text. The majority of mentions, 30 $(83 \%)$, occurred in articles originating from Australia.

\section{Grey literature sources}

The grey literature search (table 2) found 73 current mentions of SMA tools but relatively little use was made of ASIDD itself with only $12(16 \%)$ mentions. The majority of mentions related to the SMA Sports Injury Reporting Forms or to specific data items contained within them. Of the total grey literature mentions, 46 (63\%) provided copies of, or links to, the SMA forms (or modified versions). A further 11 (15\%) provided forms that contained identifiable elements from the SMA forms such as the body image or specific codes for variables such as mechanisms of injury. The SMA Sports Injury Tracker was mentioned on only four $(6 \%)$ occasions. Many of the form-related mentions originated from community-based sporting organisations (31, 43\%). Of the 52 form-related mentions where origin was known, the majority, 47 (90\%), originated from Australia.

\section{DISCUSSION}

Despite the recognised public health impact and increasing associated burden of sports injuries in Australia, ${ }^{18-20}$ there is no nationally based systematic collection of data about sports injuries to inform policy development or practitioner initiated solutions to the problem. ${ }^{21} 22$ This has not stopped the sports sector from collecting sports injury data, with many drawing on the availability of the ASIDD and associated SMA tools to assist them in their efforts.

The ASIDWP's expectations of the development of a national emergency data collection system in the early-mid 1990s did not materialise, so the need for other ways to collect sports injury data became more imperative. The Victorian Injury Surveillance Unit has presented sports data irregularly through its Hazard publications (https://www.monash.edu/muarc/research/research-areas/ home-and-community/visu/injury-by-topic). Ad-hoc reports about sports injuries published through the Australian Institute of Health and Welfare have summarised Australia-wide data. ${ }^{23}$ However, all of the hospital-based data collections either rely solely on the ICD-10-Australian Modification or other hospital-based classification schemes or have not used the ASIDD.

From a research perspective, as evidenced from the peer-reviewed literature summarised in this paper, the ASIDD and its associated forms have been useful to inform data collection activities in limited-term cohort studies published in some sports, but relatively few of these have been conducted in community sport. In the elite and professional sports contexts, there are some good Australian examples of sports-specific injury data collections (eg, the Australian Football League ${ }^{24}$ and the Australian Institute of Sport). Their data collection systems are based on tracking individual athletes in terms of their injury treatment/assessment, general well-being, training loads and so on and are not generally based on the ASIDD specifically, but do have overlapping data fields. It is not known if the ASIDD influenced the initial choice of their data fields, but this overlap could have arisen for other reasons. The fact that the document was only ever published as a grey literature source, with no accompanying or ongoing dissemination or distribution plan from a lead agency, may have also contributed to its limited uptake by such groups.

In more population and mass participation oriented clinical and sports injury prevention practitioner settings, including at local sporting clubs and by peak sports bodies, there has also been strong evidence of use of the SMA tools, especially the forms, to guide injury data collection activities. This is most evident from the grey literature. This indicates that injury prevention practitioners can be strongly engaged in injury surveillance 
Table 1 Summary of the peer-reviewed literature that has used the Australian Sports Injury Data Dictionary, SMA Sports Injury Reporting Forms or SMA-Victoria's Sports Injury Tracker

\begin{tabular}{|c|c|c|c|c|c|c|}
\hline Authors (year) (reference source) & Specific sport (where specified) & Country of Authorship & $D C^{*}$ & DAt & TD $\ddagger$ & RO§ \\
\hline \multicolumn{7}{|c|}{ Australian Sports Injury Data Dictionary (Australian Sports Injury Data Dictionary) } \\
\hline Gabbe $(1999)^{25}$ & Australian Football & Australia & & $\checkmark$ & & $\checkmark$ \\
\hline Gabbe and Finch $(2001)^{31}$ & Australian Football & Australia & & $\checkmark$ & & \\
\hline Besenyei et al $(2002)^{32}$ & $\mathrm{~N} / \mathrm{A}$ & Australia & & & & $\checkmark$ \\
\hline Gabbe et al (2002) 33 & Australian Football & Australia & & $\checkmark$ & $\checkmark$ & \\
\hline Finch $(2003)^{34}$ & All & Australia & & $\checkmark$ & & \\
\hline Peasley $(2003)^{35}$ & & Australia & & & & $\checkmark$ \\
\hline Zazryn et al (2003) & Boxing & Australia & & $\checkmark$ & $\checkmark$ & \\
\hline Zazryn et al $(2003)^{37}$ & Kick boxing & Australia & & $\checkmark$ & & \\
\hline Braham et al (2004). ${ }^{38}$ & Australian Football & Australia & & $\checkmark$ & & \\
\hline Taylor et al (2004) ${ }^{28}$ & Surfing & Australia & & & $\checkmark$ & \\
\hline Fradkin et al $(2005)^{39}$ & Golf & Australia & & $\checkmark$ & & \\
\hline Rae et al $(2005)^{40}$ & All & Australia & & & & $\checkmark$ \\
\hline Taylor et al $(2005)^{29}$ & Surfing & Australia & & $\checkmark$ & & \\
\hline Rae and Orchard $(2007)^{13}$ & All & Australia & & & & $\checkmark$ \\
\hline Rotem $(2007)^{41}$ & Rugby & Australia & & & & $\checkmark$ \\
\hline Andrew et al (2008) ${ }^{42}$ & All & Australia & & $\checkmark$ & & \\
\hline Matthews et al (2008) ${ }^{43}$ & Recreational swimming & Australia & & $\checkmark$ & & \\
\hline Shaw and Finch $(2008)^{44}$ & Cricket & Australia & & $\checkmark$ & & \\
\hline Ross $(2009)^{45}$ & All & Canada & & & & $\checkmark$ \\
\hline Smartt and Chalmers (2009) & Horse riding & New Zealand & & & & $\checkmark$ \\
\hline Zazryn et al $(2009)^{26}$ & Boxing & Australia & & $\checkmark$ & & \\
\hline Erby et al $(2010)^{30}$ & Surf lifesaving & Australia & & & $\checkmark$ & \\
\hline Gosling et al $(2010)^{47}$ & Triathlon & Australia & & & $\checkmark$ & \\
\hline Finch et al (2014) $)^{48}$ & Australian Football & Australia & & & & $\checkmark$ \\
\hline Smartt and Chalmers $(2012)^{49}$ & Snow sports & New Zealand & & $\checkmark$ & & \\
\hline Finch et al $(2013)^{50}$ & Australian Football & Australia & & & & $\checkmark$ \\
\hline Reza et al $(2013)^{51}$ & All & Iran & & & & $\checkmark$ \\
\hline Aman et al $(2014)^{52}$ & Several & Sweden & & $\checkmark$ & & \\
\hline Ekegren et al (2015) $)^{53}$ & Australian Football & Australia & & & & $\checkmark$ \\
\hline \multicolumn{7}{|c|}{ Sports Medicine Australia Injury Reporting Form (or modified version) } \\
\hline Gabbett $(2003)^{54}$ & Rugby league & Australia & $\checkmark$ & & & \\
\hline Atlas et al $(2007)^{55}$ & Multiple & Philippines & $\checkmark$ & & & \\
\hline Gianoudis et al (2008) ${ }^{56}$ & Basketball & Australia & $\checkmark$ & & & \\
\hline \multicolumn{7}{|l|}{ SMA-Victoria's Injury Tracker } \\
\hline Ekegren et al $(2014)^{57}$ & Australian Football & Australia & $\checkmark$ & & & \\
\hline Ekegren et al $(2015)^{53}$ & Australian Football & Australia & $\checkmark$ & & & \\
\hline
\end{tabular}

*DC, for data collection.

tDA, for data analysis.

‡TD, used to develop a new data collection tool.

$\S R O$, reference only.

SMA, Sports Medicine Australia.

activities when formal guidance is supported by user-friendly tools directly relevant to their settings and practice. This uptake by practitioners would have been enhanced by the fact that the SMA tools were provided free-of-charge.

Overall, this study shows that the ASIDD has a demonstrated longevity with its use continuing from 1999 to the present. ${ }^{25}$ The developers of the ASIDD aimed to create comprehensive, yet user-friendly injury surveillance guidance that could be applied by a range of practitioners in a variety of sporting contexts. The achievement of this aim is well illustrated by two investigations that have used it with practitioner data collectors with varying levels of expertise and in contrasting sporting contexts. ${ }^{26} 27$ Furthermore, the developers of the ASIDD stressed that sporting clubs and researchers could modify the data collection forms to suit their specific needs and this paper shows many examples of this, including in non-traditional sports such as surfing and surf lifesaving. ${ }^{28-30}$ These examples from the literature demonstrate that the ASIDD has achieved its aims.

Perhaps one of the major long-term legacies of the ASIDD development has been its subsequent influence on the development of new 'Activity' codes in the ICD-10. One of the particular achievements of the ASIDWP was to develop a list of sports-related activities potentially associated with injuries. Identification of the injury potential of these activities had not occurred previously. This was at the time when the ICD-9 was still in use in Australia and there were essentially only two external cause 
Table 2 Summary of the grey literature (eg, reports, presentations, web-based materials) that have used or made reference to the Australian Sports Injury Data Dictionary, or its associated sports injury reporting forms or the Sports Medicine Australia Sports Injury Tracker

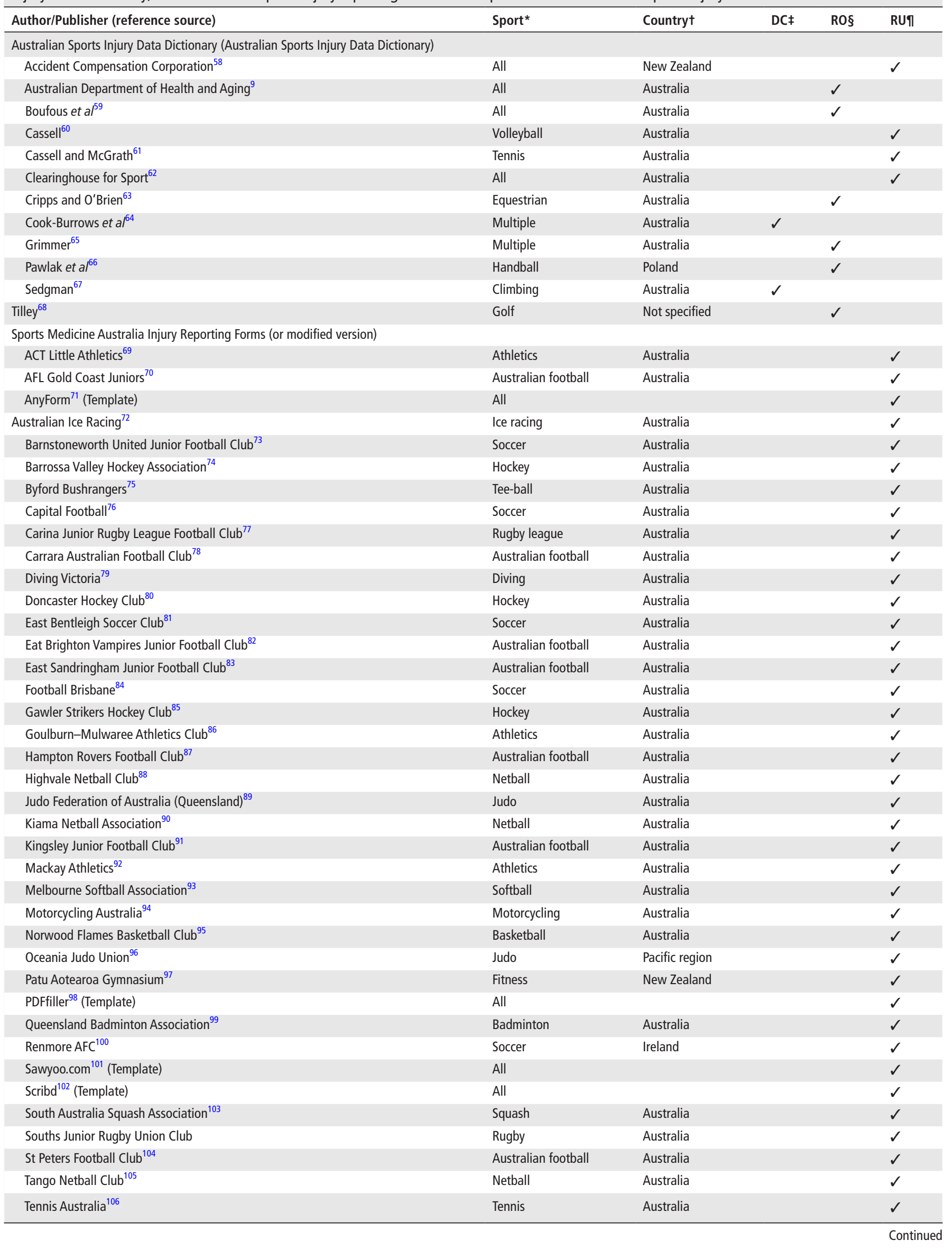




\begin{tabular}{|c|c|c|c|c|c|}
\hline Author/Publisher (reference source) & Sport* & Countryt & DCF & RO§ & RUף \\
\hline Victory Netball Club ${ }^{107}$ & Netball & Australia & & & $\checkmark$ \\
\hline Waterloo Minor Soccer Club $b^{108}$ & Soccer & Canada & & & $\checkmark$ \\
\hline Wembley Junior Football Club ${ }^{109}$ & Australian football & Australia & & & $\checkmark$ \\
\hline Western Region Academy of Sport ${ }^{110}$ & Several & Australia & & & $\checkmark$ \\
\hline Woodvale Football Club ${ }^{111}$ & Soccer & Australia & & & $\checkmark$ \\
\hline WordLayouts $^{112}$ (Template) & All & & & & $\checkmark$ \\
\hline Yerrinbool-Bargo Soccer Club ${ }^{113}$ & Soccer & Australia & & & $\checkmark$ \\
\hline \multicolumn{6}{|c|}{ Form contains identifiable elements of Sports Medicine Australia Injury Reporting Form } \\
\hline Association Heads of Independent Girls Schools ${ }^{114}$ & All & Australia & & & $\checkmark$ \\
\hline Ballina Netball Association ${ }^{115}$ & Netball & Australia & & & $\checkmark$ \\
\hline Blaxland Football Club ${ }^{116}$ & Soccer & Australia & & & $\checkmark$ \\
\hline Canning Vale Junior Football Club ${ }^{117}$ & Australian football & Australia & & & $\checkmark$ \\
\hline Football New South Wales ${ }^{118}$ & Soccer & Australia & & & $\checkmark$ \\
\hline Football South Coast ${ }^{119}$ & Soccer & Australia & & & $\checkmark$ \\
\hline Greyhound Racing New South Wales ${ }^{120}$ & Greyhound racing & Australia & & & $\checkmark$ \\
\hline Gymnastics Australia ${ }^{121}$ & Gymnastics & Australia & & & $\checkmark$ \\
\hline Club $10^{122}$ & Gymnastics & Australia & & & $\checkmark$ \\
\hline Indoor Beach Volley Ball Federation of Western Australia ${ }^{123}$ & Volleyball & Australia & & & $\checkmark$ \\
\hline Khalifa University ${ }^{124}$ & All & UAE & & & $\checkmark$ \\
\hline \multicolumn{6}{|l|}{ SMA-Victoria's Injury Tracker } \\
\hline Clearinghouse for Sport ${ }^{62}$ & All & Australia & & $\checkmark$ & \\
\hline Netball Victoria ${ }^{125}$ & Netball & Australia & & & $\checkmark$ \\
\hline Skate Victoria ${ }^{126}$ & Roller skating & Australia & & & $\checkmark$ \\
\hline Sport and Recreation Tasmania ${ }^{127}$ & All & Australia & & & $\checkmark$ \\
\hline
\end{tabular}

* Specific sport (where specified).

+ Country of authrship or website host.

$++D C$, for data collection.

$\& R U$, reference only.

\#RU, recommended or required use.

codes that could be used to identify sports injury (collisions in sport and falls in sport). The then Director of the National Injury Surveillance Unit at Flinders University provided a direct link between the ASIDWP and ongoing national and international developments of the ICD external cause codes. Through these connections, the ASIDD sports activity list was provided to the ICD-10 development team, which used this as the basis of the Activity codes in the ICD-10, and similar modifications worldwide. The original ASIDD list was considered by the International Collaborative Effort of Causes of Injury and the Centres of Disease Control (USA) and extended to the 200+ longlist now used in the ICD-10 to ensure global relevance.

This review is limited by the completeness of the literature search process, especially as a variety of wording was used to reference the ASIDD and the SMA tools. We aimed to be comprehensive, but it is possible that some authors referenced the ASIDD differently and that many others did not reference it at all.

It is likely that we did not capture the full use of SMA tools, especially in the grey literature. While there is likely to be good capture from the peer-reviewed literature, as publication standards require the acknowledgement of sources, this may not apply equally in the grey literature. Many of the mentions in the grey literature make no acknowledgement of the sources. For example, through the Google Image search, it was found that several community sports organisations appeared to have used the ASIDD body chart in their own injury reporting form but did not identify the source of this. It is also known that the
Sports Trainer training courses provided by SMA over the past 20 years have included modules on injury data collection based on the SMA tools. However, the course manuals underpinning this training are either not available online or do not explicitly mention the source of the recommended injury data collection tools. Nonetheless, this demonstrates the value of including the image search in our strategy to identify uses of ASIDD and the SMA tools.

\section{CONCLUSION}

Widespread availability of guidance to underpin ongoing activities, such as the ASIDD and its associated tools, has the potential to contribute to ongoing sports injury data collections both in Australia and internationally. The landscape of sports injury is constantly evolving with changes in the rules of competition, equipment, practices to prevent and treat sports injury and the development of or increased attractiveness of new sports and modes of physical activity. With the heightened awareness for the need to provide safe sporting and physical activity opportunities continually, and the global need for data collections to support this, this study contributes important information about the value of publically available sports injury data guidance. This study has shown widespread and current use of the ASIDD and SMA tool resources, particularly by Australian sports injury practitioners and researchers from both Australia and other countries, demonstrating that guidance on how to conduct sports injury surveillance is needed, and used by, by the sector. 
Given this, the value of having such resources available to the general sporting community as open-access resources that can be adapted to local contexts, is very apparent. However, given the very large advances in digital technology, data capture systems and data analysis approaches that have been made since the initial publication of ASIDD, future efforts could focus on making refinements to the resources to ensure they meet today's information needs. Future efforts will also need to comply with the developing international regulations around data protection. It is recommended that, where possible, both researchers and sports injury surveillance practitioners should cite ASIDD both in their references and as a keyword to allow its use to be monitored. In Australia, government departments of Sport and Recreation have increasingly been placed within broader government portfolios of health. Convincing the larger health portfolios of the need to invest in sports safety requires evidence of major impacts on, burden of, injuries on health service delivery systems. This in turn requires high-quality injury surveillance. Much of the focus in the sports injury literature to date has been directly on defining sports injury only. The lessons learnt from this evaluation of the impact of ASIDD can now be used to also inform the establishment and refinement of injury surveillance systems and data collection platforms to underpin sports injury data collections more globally.

What is already known on this subject?

- Sports injuries are known to be a public health issue and to place significant burden on both injured people and healthcare delivery systems. They are a priority prevention target.

- Injury prevention needs to be underpinned by high quality relevant injury surveillance data.

- Specific guidance in what data to collect as part of injury surveillance, and how to code it, is useful.

\section{What this study adds?}

- The Australian Sports Injury Data Dictionary facilitates injury surveillance through its provision of specific coding guidance and readily available specific data collection forms specifically for sports injury surveillance in relevant settings and communities.

- Injury prevention practitioners can be strongly engaged in injury surveillance activities when formal guidance is supported by user-friendly tools directly relevant to their settings and practice.

Acknowledgements The Australian Centre for Research into Injury in Sport and itsPrevention (ACRISP) is one of the International Research Centres for the Prevention of Injury and Protection of Athlete Health supported by the International Olympic Committee (IOC). Dr Scott Talpey is thanked for his contributions to the early stages of this research. Dr Lauren Fortington is thanked for her comments on an earlier version of this paper.

Contributors CFF conceived and designed this study. CS undertook the literature review, collation and categorisation. Both authors contributed to the writing and editing of the manuscript and approved this manuscript for submission.

Competing interests None declared.

Provenance and peer review Not commissioned; externally peer reviewed.

Data sharing statement As this is a review, no data are available for sharing.

Open access This is an open access article distributed in accordance with the Creative Commons Attribution Non Commercial (CC BY-NC 4.0) license, which permits others to distribute, remix, adapt, build upon this work non-commercially, and license their derivative works on different terms, provided the original work is properly cited and the use is non-commercial. See: http://creativecommons.org/ licenses/by-nc/4.0/

(C) Article author(s) (or their employer(s) unless otherwise stated in the text of the article) 2018. All rights reserved. No commercial use is permitted unless otherwise expressly granted.

\section{REFERENCES}

1 Finch C. A new framework for research leading to sports injury prevention. J Sci Med Sport 2006:9:3-9.

2 Finch CF. An overview of some definitional issues for sports injury surveillance. Sports Med 1997:24:157-63.

3 Ekegren CL, Gabbe BJ, Finch CF. Sports injury surveillance systems: a review of methods and data quality. Sports Med 2016:46:49-65.

4 Dick R, Agel J, Marshall S. National collegiate athletic association injury surveillance system commentaries: introduction and methods. J Ath/ Train 2007:42:173-82.

5 Junge A, Engebretsen L, Alonso JM, et al. Injury surveillance in multi-sport events: the International Olympic Committee approach. Br J Sports Med 2008;42:413-21.

6 Australian Sports Injury Data Working Party. Australian sports injury data dictionary. 1998 http://sma.org.au/resources-advice/sports-injuries/sports-injury-datadictionary/ (accessed 11 Aug 2017).

7 National Injury Prevention Advisory Council. Directions in injury prevention. Report 1: research needs. Canberra: Commonwealth Department of Health and Aged Care, 1999.

8 National Injury Prevention Advisory Council. Directions in injury prevention. Report 2: Injury prevention interventions - good buys for the next decade. Canberra: Commonwealth Department of Health and Aged Care, 1999.

9 Department of Health and Ageing. Sports Safety in Australia: an update. July 2003. Canberra: Australian Government Department of Health and Ageing, 2004.

10 Mitchell RJ, McClure RJ, Williamson AM, et al. Implementing the national priorities for injury surveillance. Med J Aust 2008;188:405-8.

11 Australian Sports Commission. Sportsafe australia. a national sports safety framework - a report prepared for the australian sports injury prevention taskforce. Belconnen, ACT, Australia: Australian Sports Commission, 1997. http://nla.gov.au/ nla.cat-vn191043. (accessed 11 Aug 2017).

12 Finch C, Ozanne-Smith J, Williams F. The feasibility of improved data collection methodologies for sports injuries: Monash University Accident Research Centre Report. 69, 1995. http://www.monash.edu/muarc/research/our-publications/ muarc069.

13 Rae K, Orchard J. The Orchard Sports Injury Classification System (OSICS) Version 10. Clin J Sport Med 2007:17:201-4.

14 World Health Organization. International Classification of External Causes of Injury (ICECI). 2017 http://www.who.int/classifications/icd/adaptations/iceci/en/ (accessed 13 Mar 2017).

15 McGuineess B, Leeder T. A standardised data collection methodology for sports injury surveillance - computerised data entry and analysis system. HIC '96, Fourth National Health Informatics Conference. Melbourne, Australia: Health Informatics Society of Australia, 1996.

16 Finch CF, Valuri G, Ozanne-Smith J. Injury surveillance during medical coverage of sporting events - development and testing of a standardised data collection form. J Sci Med Sport 1999:2:42-56.

17 Orchard JW, McCrory P, Makdissi M, et al. Use of rule changes to prevent injury in the Australian Football League. J Ortho E Trauma 2014;65:355-64.

18 Finch C, Cassell $\mathrm{E}$. The public health impact of injury during sport and active recreation. J Sci Med Sport 2006;9:490-7.

19 Finch CF, Wong Shee A, Clapperton A. Time to add a new priority target for child injury prevention? The case for an excess burden associated with sport and exercise injury: population-based study. BMJ Open 2014;4:e005043.

20 Finch CF, Kemp JL, Clapperton AJ. The incidence and burden of hospital-treated sports-related injury in people aged 15+ years in Victoria, Australia, 2004-2010: a future epidemic of osteoarthritis? Osteoarthritis Cartilage 2015;23:1138-43.

21 Orchard JW, Finch CF. Australia needs to follow New Zealand's lead on sports injuries. MJA 2002;177:38-9.

22 Finch C. Better data reporting will prevent sports injuries and deaths. 2014 http:// theconversation.com/better-data-reporting-will-prevent-sports-injuries-and-deaths 34797 (accessed 12 Dec 2016).

23 Flood L, Harrison JE. Hospitalised sports injury, Australia 2002-03. Flinders University. Adelaide: Australian Institute of Health and Welfare, 2006

24 Orchard JW, Seward H, Orchard JJ. Results of 2 decades of injury surveillance and public release of data in the Australian Football League. Am J Sports Med 2013:41:734-41.

25 Gabbe B. Descriptive epidemiology of Australian football injuries presenting to sports medicine clinics: Masters of Applied Science Thesis, Deakin University, 1999.

26 Zazryn TR, McCrory PR, Cameron PA. Injury rates and risk factors in competitive professional boxing. Clin J Sport Med 2009;19:20-5. 
27 Ekegren CL, Gabbe BJ, Finch CF. Injury surveillance in community sport: can we obtain valid data from sports trainers? Scand J Med Sci Sports 2015;25:315-22.

28 Taylor DM, Bennett D, Carter M, et al. Acute injury and chronic disability resulting from surfboard riding. J Sci Med Sport 2004;7:429-37.

29 Taylor DM, Bennett D, Carter M, et al. Perceptions of surfboard riders regarding the need for protective headgear. Wilderness Environ Med 2005;16:75-80.

30 Erby $\mathrm{R}$, Heard R, O'Loughlin K. Trial of an injury reporting system for surf lifesavers in Australia. Work 2010:36:181-92.

31 Gabbe B, Finch C. A profile of Australian football injuries presenting to sports medicine clinics. J Sci Med Sport 2001;4:386-95.

32 Besenyei A, Waller G, Wood S. Quality assurance partnerships of the National Centre for Classification in Health. health informatics conference 2002: improving quality by lowering barriers, 2002. http://catalogue.nla.gov.au/Record/2068921 (accessed 11 Aug 2017).

33 Gabbe B, Finch C, Wajswelner $\mathrm{H}$, et al. Australian football: injury profile at the community level. J Sci Med Sport 2002;5:149-60.

34 Finch $\mathrm{C}$. How useful are insurance claim data for sports injury prevention purposes? Inj Control Saf Promot 2003;10:181-3.

35 Peasley K, Wood S. Developing and managing the national coroners' information system for Australia. Health Information Management 2003;31:20-3.

36 Zazryn TR, Finch CF, McCrory P. A 16 year study of injuries to professional boxers in the state of Victoria, Australia. Br J Sports Med 2003;37:321-4.

37 Zazryn TR, Finch CF, McCrory P. A 16 year study of injuries to professional kickboxers in the state of Victoria, Australia. Br J Sports Med 2003;37:448-51.

38 Braham R, Finch CF, McIntosh A, et al. Community level Australian Football: a profile of injuries. J Sci Med Sport 2004;7:96-105.

39 Fradkin AJ, Cameron PA, Gabbe BJ. Golf injuries-common and potentially avoidable. I Sci Med Sport 2005;8:163-70.

40 Rae K, Britt H, Orchard J, et al. Classifying sports medicine diagnoses: a comparison of the International classification of diseases 10-Australian modification (ICD-10AM) and the Orchard sports injury classification system (OSICS-8). Br J Sports Med 2005;39:907-11.

41 Rotem T. Epidemiology of catastrophic rugby football injuries in New South Wales PhD Thesis: Faculty of Medicine, University of New South Wales, 2007.

42 Andrew NE, Gabbe BJ, Wolfe R, et al. Twelve-month outcomes of serious orthopaedic sport and active recreation-related injuries admitted to Level 1 trauma centers in Melbourne, Australia. Clin J Sport Med 2008;18:387-93.

43 Matthews BL, Thom A, Franklin RC. Injuries in public swimming pools in victoria: a pilot study. IJARE 2008;2:106-13.

44 Shaw L, Finch CF. Injuries to junior club cricketers: the effect of helmet regulations. Br J Sports Med 2008;42:437-40

45 Ross AD. An examination of intercollegiate athletic injury tracking systems within Canadian universities [PhD Thesis]. Ontario: Wilfrid Laurier University, 2009

46 Smartt P, Chalmers D. A new look at horse-related sport and recreational injury in New Zealand. J Sci Med Sport 2009;12:376-82.

47 Gosling CM, Forbes AB, McGivern J, et al. A profile of injuries in athletes seeking treatment during a triathlon race series. Am J Sports Med 2010;38:1007-14.

48 Finch CF, Orchard JW, Twomey DM, et al. Coding OSICS sports injury diagnoses in epidemiological studies: does the background of the coder matter? Br I Sports Med 2014:48:552-6.

49 Smartt PFM, Chalmers DJ. Searching hospital discharge records for snow sport injury: no easy run? Int J Inj Contr Saf Promot 2012;19:93-100.

50 Finch $C F$, Gabbe $B$, White $P$, et al. Priorities for investment in injury prevention in community Australian football. Clin J Sport Med 2013;23:430-8.

51 Reza S, Ahmad R, Ramin K, et al. Comparison of nomenclature and classification systems of sport injuries in elected countries with Iran. Adv Environ Biol 2013:7:4390-2.

52 Aman M, Forssblad M, Henriksson-Larsen K. Insurance claims data: a possible solution for a national sports injury surveillance system? An evaluation of data information against ASIDD and consensus statements on sports injury surveillance. BMJ Open 2014:4:e005056.

53 Ekegren CL, Gabbe BJ, Donaldson A, et al. Injuries in community-level Australian football: Results from a club-based injury surveillance system. J Sci Med Sport 2015;18:651-5.

54 Gabbett TJ. Incidence of injury in semi-professional rugby league players. Br J Sports Med 2003;37:36-44.

55 Atlas A, Dones V, Lizarondo L, et al. Injuries of University of Santo Tomas college teams during the University Athletics Association of the Philippines Season 69. Phillipine J Allied HIth Sci 2007;2:26-31.

56 Gianoudis J, Webster KE, Cook J. Volume of physical activity and injury occurrence in young basketball players. J Sports Sci Med 2008;7:139-43.

57 Ekegren CL, Donaldson A, Gabbe BJ, et al. Implementing injury surveillance systems alongside injury prevention programs: evaluation of an online surveillance system in a community setting. Inj Epidemiol 2014;1:19.

58 Accident Compensation Corporation. ACC sportssmart: play smart go the distance. educational resources. 2008. http://www.acc.co.nz/sportsmart (accessed 13 Mar2017).
59 Boufous S, Dennis R, Finch C. A profile of hospitalisations and deaths due to sport and leisure injuries in New South Wales, 2000-2004. 2006 http://www.irmrc.unsw. edu.au/documents/irmrcSportsInjuryReport.pdf (accessed 11 Aug 2017).

60 Cassell E. Spiking injuries out of volleyball: a review of injury countermeasures. 2001. http://www.monash.edu/muarc/research/our-publications/muarc181 (accessed 13 Mar 2017)

61 Cassell E, McGrath A. Lobbying injury out of tennis: areview of the literature. 1999 http://www.monash.edu/muarc/research/our-publications/muarc144 (accessed 13 Mar 2017).

62 Richards R. Cost of sports injuries - research and data collection. https://www.clea ringhouseforsport.gov.au/knowledge_base/sport_participation/sport_injuries_and_ medical_conditions/sports injuries (accessed 13 Mar 2017).

63 Cripps R, O'Brien D. Monitoring falls during eventing: establishment of a national surveillance system to monitor injury to riders and horses from falls during the crosscountry phase of eventing in Australia: a report for the Rural Industries Research and Development Corporation. 2004. http://catalogue.nla.gov.au/Record/514292 (accessed 13 Aug 2017).

64 Cook-Burrows W, Matthews D, Wallner F. Illawarra sports injury report 2001 Illawarra: Healthy Cities Illawarra Inc, 2001.

65 Grimmer K. Young people's participation in sports and recreational activities, and associated injury: Australian Centre for Allied Health Research, University of South Australia, 1999

66 Pawlak M, Lubiatowski $\mathrm{P}$, et al. Sport injury and overuse surveillance in handballreview of systems and new proposal. https://members.ehf.eu/community/activities/ download.ashx? reason=ehfcanFile\&id=2259 (accessed 13 Aug 2017).

67 Sedgman IB. Climbing accidents in Australia: 1955-2004: University of Ballarat, 2004.

68 Tilley N. Mechanisms of injury in golf. 2009. http://www.professionalevents.co.uk/ images/_products2downloads/109_317.pdf (accessed 13 Aug 2017).

69 Australian Capital Territory (ACT) Little Athletics. ACT Little athletics risk management safety audit plan. 2003. http://www.actlaa.org.au/Portals/46/ Documents/Resources/ACTLAA\%20Safety\%20Audit\%20Plan\%20V3.pdf (accessed 13 Mar 2017).

70 Australian Football League (AFL) Gold Coast Juniors. Injury report form. http:// websites.sportstg.com/assoc_page.cgi?c=0-4608-0-0-0\&sID=276301 (accessed 13 Mar 2017).

71 Waterloo Minor Soccer Club. Waterloo Minor Soccer Club injury report form. http:// anyform.org/doc/106143/waterloo-minor-soccer-club-injury-report-form (accessed 13 Mar 2017).

72 Australian Ice Racing (AIR). AIR sports injury incident report form 2013. http://www. australianiceracing.org/members/insurance/ (accessed 13 Mar 2017).

73 Barnstoneworth United Junior Football Club. Team Manager Information - Player injury/accident report. 2015 http://www.bujfc.com/teaminfo/ (accessed 13 Mar 2017).

74 Barrossa Valley Hockey Association. Injury report form. http://www.barossahockey. com/customdata/index.cfm?fuseaction=Display_Image_Listing\&CategorylD= 16849\&OrgID=11563 (accessed 13 March 2017).

75 Byford Bushrangers. Coaching tools - Tee-ball injury reporting form. http:// bushrangers.org.au/public/pages/coaching (Accessed 13 March 2017).

76 Australian Capital Territory (ACT) Football Federation. Policy for visiting or hosting teams Capital football accident report form. 2011. http://www.capitalfootball. com.au/sites/default/files/Visiting\%20Teams\%20Policy(2).pdf (accessed 13 Mar 2017).

77 Carina Junior Rugby League Football Club. Rugby league injury reporting form. 2016. http://www.carinajuniors.com.au/media/14962/Rugby-League-InjuryReporting-Form.pdf (accessed 12 Dec 2016).

78 Carrara Australian Football Club. Injury reporting form. http://websites.sportstg.com/ club_info.cgi?c=1-4608-97090-327283-0\&sID=323412 (accessed 12 Dec 2016).

79 Diving Victoria. Report and investigation policy Injury/illness reporting form. https://s3-ap-southeast-2.amazonaws.com/piano.revolutionise.com.au/cups/ divingvic/files/DV\%20Accident\%20Reporting\%20Policy.pdf (accessed 12 Dec 2016).

80 Doncaster Hockey Club. Resources. Team managers. Player injury report form. http:// doncasterhockeyclub.com.au/resources/team-managers/\#other_forms (accessed 13 Mar 2017)

81 East Bentleigh Soccer Club (ESBC). EBSC policy documents - injury reporting form. http://www.eastbentleighsc.com/club-policies.html (accessed 12 Dec 2016).

82 East Brighton Vampires Junior Football Club. trainers help. 2015 http://103.37.8.109/ govampir/wp-content/uploads/2016/03/ebvjfc-2015-trainersguide.pdf (accessed 12 Dec 2016).

83 East Sandringham Junior Football Club. Forms. Issues management - injury reporting form. http://www.gozebs.com/team-managers.php?Forms-1 (accessed 12 Dec 2016)

84 Football Brisbane. Football injury reporting form. http://www.footballbrisbane.com. au/injury-management (accessed 12 Dec 2016).

85 Gawler Strikers Hockey Club. Injury report form. http://www.gawlerhockeyclub.com/ customdata/index.cfm?fuseaction=display main\&ltemID=68426\&OrgID=11575 (accessed 12 Dec 2016). 
86 Goulburn-Mulwaree Athletics Club. Goulburn-mulwaree athletics club safety plan. 2016 http://gmlac.org.au/wp-content/uploads/2016/09/Goulburn-MulwareeAthletics-Club-Safety-Plan-version-9-Sept-2016.pdf (accessed 12 Dec 2016).

87 Hampton Rovers Football Club. Injury reporting form. http://www.hamptonrovers. com.au/club/policies.php (accessed 12 Dec 2016).

88 Highvale Netball Club. SMA injury reporting form. http://www. highvalenetball.org. au/wp-content/uploads/2014/05/SMA-injury-reporting-form.pdf (accessed 12 Dec 2016).

89 Judo Federation of Australia Queensland (JFAQ). JFA(Q) injury report form. http:// www.jfaq.com.au/index.php?uv=85I0I0I0I0I0I0I0 (accessed 12 Dec 2017).

90 Kiama Netball Association (KNA). KNA injury reporting form. http://kiamanetball. com.au/index.php?option=com_content\&view=article\&id=134\&ltemid $=142$ (accessed 12 Dec 2016).

91 Kingsley Junior Football Club. Australian Football injury reporting form. 2013. http:// www.kingsleyjfc.com.au/docs_injurymgmt.html (accessed 12 Dec 2016).

92 Mackay Athletics. Injury report form. http://www.mackayathletics.com.au/web/ policies.html (accessed 12 Dec 2016).

93 Melbourne Softball Association. Injury reporting form. $2014 \mathrm{http}: / /$ melbournesoftball. org.au/competition/injury-reporting-form/ (accessed 12 Dec 2016).

94 Motorcycling Australia (MA). Officials event forms - MA injury report form. http:// www.ma.org.au/index.php?id=746 (accessed 12 Dec 2016).

95 Norwood Flames Basketball Club. Incident and injury report. http://www. norwoodbasketball.com.au/incident-report (accessed 12 Dec 2016).

96 Oceania Judo Union. Medical manual for judo. 2014 http://oceaniajudo.org/wpcontent/uploads/2014/12/Medical_Manual-edit-2014.pdf (accessed 12 Dec 2016).

97 Patu Aotearoa Gymnasium. Safety procedures manual. Record of accident or serious harm. 2013 http://www.youblisher.com/p/762817-PATU-AOTEAROA/ (accessed 12 Dec 2016).

98 Sports Medicine Australia. Fillable rugby union injury report form. https://www pdffiller.com/314587997-ddunionpdf-Rugby-Union-Injury-Report-Form-SportsMedicine-Australia-Various-Fillable-Forms (accessed 12 Dec 2016).

99 Queensland Badminton Association. Risk management policy. http://www.qba.net. au/pages/indexp.asp?pageid=92 (Accessed 12 Dec 2016).

100 Renmore Australian Football Club (AFC). Renmore AFC injury report form. http:// www.renmoreafc.com/Renmore_AFC_Injury_report_form.pdf (accessed 12 Dec 2017).

101 TemplateFans. Injury report template. 2013 http://www.sawyoo.com/post firstreport-of-injury-template_661355/ (accessed 13 Aug 2017).

102 Anon. Injury report form. https://www.scribd.com/document/321514461/Untitled (accessed 12 Dec 2016)

103 South Australia Squash Association. Injury report template - Squash SA. http://www. squashsa.asn.au/_literature./Injury_Report_Form_Template (accessed 12 Dec 2016)

104 St Peters Football Club. Injury report form. http://websites.sportstg.com/club_info. cgi?c=1-4901-70195-213886-14756024\&sID=209406 (accessed 12 Dec 2017).

105 Tango Netball Club. Forms for coaches - injury report form. http://www. tangonetballclub.com.au/club-information/coaches-corner/ (accessed 12 Dec 2016).

106 Tennis Australia. Injury report form - general. http://www.tennis.com.au/leganatc/ files/2012/12/3c.-Injury report form.pdf (accessed 12 Dec 2016).

107 Victory Netball Club. Handbook. 2016 https://www.vcc.vic.edu.au/images/ downloads/VNC-handbook.pdf (accessed 12 Dec 2016)
108 Waterloo Minor Soccer Club. Injury report form. http://www.waterloounited.com/wpcontent/uploads/2014/07/Concusion-Policy-Injury-Report-Form.pdf (accessed 12 Dec 2016).

109 Wembley Junior Football Club. Resources - injury report. http://www. wembleyjuniormagpies.com/resources.htm (accessed 12 Dec 2016).

110 Western Region Academy of Sport. Sports injury tracker. http://wras.org.au/ downloads/ (accessed 12 Dec 2016)

111 Woodvale Football Club. Downloads and references - inury report. http://wfc. myclubwebsite.com.au/club-information/club-downloads/ (accessed 12 Dec 2016).

112 WordLayouts. Injury form template. https://www.wordlayouts.com/injury-formtemplate/ (accessed 13 Aug 2017)

113 Yerrinbool-Bargo Soccer Club. Rules, regulations and policies - soccer injury reporting form. http://websites.sportstg.com/club_info.cgi?c=1-4746-114530-0-0\&sID= 267741 (accessed 12 Dec 2016).

114 Independent Girls Schools Sports Association (IGSSA) Sporting Committee. Policies - accidents and injuries. http://www.ahigs.nsw.edu.au/IGSSA/Policies/ AccidentsandInjuries.aspx (accessed 13 Aug 2017).

115 Ballina Netball Association. Forms - injury reporting form. http://ballinana.nsw. netball.com.au/files/39133/files/2016\%20Season/Injury_report_form.pdf.

116 Blaxland Football Club. Forms - personal injury claim form. http://www. blaxlandfootball.com/forms (accessed 13 March 2017).

117 Canning Vale Junior Football Club. Documents- JLT personal injury claims. http:// cvjfc.com.au/documents/forms/injury-claim-form (accessed 13 March 2017).

118 Football New South Wales. How to make a personal injury claim - Personal injury claim form. https://www.jltsport.com.au/fnsw/making-a-claim (accessed 12 Dec 2016).

119 Football South Coast. Injury/insurance forms - JLT sport personal injury claim form. http://websites.sportstg.com/assoc_page.cgi?c=0-4704-0-0-0\&sID=317614

120 Greyhound Racing New South Wales. Standard 11: Incident and injury reporting. 2011. http://grnsw.com.au/uploads/Standard\%2011\%20-\%20Incident $\% 20 \% 26 \%$ 20Injury\%20Reporting.pdf (accessed 12 Dec 2016).

121 Gymnastics Australia. Personal injury claims - Gymnastics Australia's personal injury claim form. https://gymnastics.jltsport.com.au/claims-personal-injury (accessed 12 Dec 2016).

122 Gymnastics Australia. Information sheet - making a claim How to lodge a personal injury claim. http://gymnastics.org.au/Ga/Club_Development/Club_Affiliation/How_ to_Claim.aspx (accessed 13 Mar 2017).

123 Indoor Beach Volley Ball Federation of Western Australia. Erdinger Alkoholfrei Super League Players Manual. 2016 http://indoorbeachvolleyball.com/wp-content/uploads/ Player-Manual-2016.pdf (accessed 12 Dec 2016).

124 Khalifa University. Emergencies - report incidents. http://www.kustar.ac.ae/pages/ environment-health-and-safety-for-ku-students (accessed 12 Dec 2016).

125 Netball Victoria. Sports injury tracker. http://nvclubhouse.com.au/document/966/ sports-injury-tracker (accessed 12 Dec 2016).

126 Skate Victoria. Insurance-injury tracker. http://www.skatevictoria.com.au/documentsand-policies/ (accessed 12 Dec 2016).

127 Sport and Recreation Tasmania. 10. Risk management resources. http://www.dpac tas.gov.au/_data/assets/pdf_file/0009/228537/10.Resources.pdf (accessed 12 Dec 2016) 